Como passar para os demais a experiência maravilhosa de ser aluno de Sílvia Lane, que formou aproximadamente 100 mestres e doutores?

A opção foi fazê-lo por meio de depoimentos de professores que foram alunos de Sílvia Lane, tendo sido influenciados por suas idéias no campo da Psicologia Social, e pelo seu exemplo de ser humano inquieto e sempre na busca de uma Psicologia engajada que aporta importantes contribuições para a solução dos problemas sociais.

O professor Antônio da Costa Ciampa, da Pontifícia Universidade Católica de São Paulo (PUC-SP), aluno, amigo e posteriormente colega de Sílvia Lane, relata a influência de Sílvia na sua crença de que nascemos para começar e não para terminar e que, nesta luta, cada começo pode trazer a emancipação humana.

A professora Margarida Barreto, doutora em Psicologia Social e pesquisadora do Núcleo de Estudos Psicossociais de Exclusão e Inclusão Social (NEXIN) da PUC-SP, nos relembra importantes aspectos do pensamento de Sílvia Lane, afirmando que é impossível pensar a história da Psicologia Social, no Brasil e na América Latina, sem revelar a identidade viva, doce e humana de Sílvia Lane, mais ao mesmo tempo firme, persistente, combativa e crítica intransigente das idéias positivistas e conservadoras.

A professora Ana Lúcia Artioli, da Universidade do Estado de Mato Grosso, orientanda da Sílvia até pouco antes da sua morte, dá um depoimento comovente de como foi rica a convivência com a mestra.

A professora Célia Ferraz, da Escola Superior de Propaganda e Marketing de São Paulo (ESPM-SP) - Setor Pós Graduação, também orientanda de Sílvia Lane, encerra os depoimentos, apresentando a agenda de trabalho dos últimos meses de vida da professora Sílvia, deixando a cada um dos leitores as suas preocupações naqueles últimos dias e seu grande amor pela psicologia social, pela docência e pesquisa.

\title{
SÍLVIA LANE: O HOMEM EM MOVIMENTO
}

\section{Antônio da Costa Ciampa \\ Pontifícia Universidade Católica de São Paulo, São Paulo, Brasil}

A inevitabilidade da morte é a única certeza que todos nós podemos ter, como uma contingência da vida.

Contudo, muitos dos que, como eu, convivemos com Sílvia Lane, podemos aceitar uma outra certeza, a certeza de que nascemos para começar - e não de que nascemos para morrer - pois, como diz Hanna Arendt, há "um começo que vem ao mundo quando nascemos ... . começando algo novo, por nossa própria iniciativa" (" $A$ condição humana", 1983, p. 190). O sentido que essa autora atribui ao agir retrata como Sílvia Lane agia durante toda sua vida: tomar iniciativa, iniciar, imprimir movimento a algo.

Sílvia Lane e Hanna Arendt, cada uma a seu modo, falaram do homem em movimento, preocupadas com a existência de homens concretos - não de um abstrato Homem (com maiúscula) - mas de homens que, dentro da história, vivem em sociedade e habitam o mundo, reconhecendo e enfatizando que essa existência sempre tem relação com a política.
Sempre vi a Sílvia começando algo, algo que ela sempre concluía de forma que o final fosse um novo começo.

Não me parece que aqui seja lugar para falar de suas valiosas e numerosas realizações, pois muito haveria que falar, mesmo porque meu primeiro contato com ela foi em 1965. Durante mais de quatro décadas tive o privilégio de, com ternura e carinho, fruir de sua amizade e camaradagem, enquanto, com admiração e respeito, muito aprendia com ela, primeiro como aluno, depois como orientando e, finalmente, como colega.

Não há como destacar a importância que a Sílvia teve - e continua tendo ainda hoje - para mim, sem parecer que estou exagerando. Ela me ajudou muito - e ainda ajuda quando necessário - a acreditar que há uma vida que vale a pena ser vivida, uma vida que seja a constante e permanente luta pela emancipação humana.

Se eu falo de mim é apenas para evidenciar o que considero sempre foi muito próprio da Sílvia, ou seja, ao mesmo tempo em que sempre estava começando algo, 
ela estimulava os outros a também começarem algo por sua própria iniciativa. Creio que isso revela o sentido profundamente humano e fortemente democrático que ela sempre procurou imprimir às suas ações: criar condições que aumentassem a autonomia do outro, para permitir o desenvolvimento de relações mais libertárias e igualitárias com ele.

Há mais de vinte anos ela teve a iniciativa de lançar o livro $O$ homem em movimento. Ele foi marco de uma grande transformação da Psicologia Social brasileira. Ele hoje pode ser visto, ao mesmo tempo, como uma orientação e como um desafio.

A orientação básica é ter sempre o objetivo de contribuirmos para uma psicologia voltada para os problemas concretos de nossa realidade, tornando-nos participantes do esforço de transformação da sociedade brasileira. Neste sentido, valoriza tanto a atividade de pesquisa empírica, como a de sistematização teórica, propondo uma psicologia que sempre considere a questão da linguagem como fundamental, no estudo da atividade, da consciência, da afetividade e da identidade, "não esquecendo jamais que estas categorias estão em mútua interdependência", como afirma em "Novas veredas da Psicologia Social” (1995, p. 59). Conclui isso de forma que o final se torna um novo começo.

Assim, o desafio é não abandonar a concepção, que lançou há mais de vinte anos, de homem em movimento, de tal modo a continuarmos a nos perguntar como isso pode ser feito hoje.

Já que, infelizmente, a Sílvia não está mais entre nós, se queremos manter vivo seu verdadeiro espírito - o que seria uma forma de imortalidade - devemos enfrentar esse desafio de continuarmos a buscar novas respostas à questão de como desenvolver uma psicologia voltada para os problemas concretos de nossa realidade atual.

Sua recusa a qualquer forma de dogma fica evidente numa frase que sempre valorizou e gostava de repetir: porque não? Entendo que a maior homenagem que podemos prestar à Sílvia Lane é agir como ela agiu durante toda sua vida: tomar iniciativa, iniciar, imprimir movimento a algo, sempre com o foco no homem em movimento, que ela sempre encarnou de forma emblemática.

Antonio da Costa Ciampa é doutor em Psicologia Social. Professor Associado de Pós-graduação em Psicologia Social da Pontifícia Universidade Católica de São Paulo (PUC-SP). Endereço para correspondência: PUC-SP, Setor de Pós Graduação em Psicologia Social.

Rua Monte Alegre, 984, Perdizes São Paulo, SP acciampa@pucsp.br

\title{
SÍLVIA LANE: A MULHER QUE FERMENTOU IDÉIAS E ALIMENTOU AÇÕES TRANSFORMADORAS
}

\author{
Margarida Barreto \\ Sindicato dos Trabalhadores nas Indústrias Químicas e Plásticas de São Paulo, São Paulo, Brasil
}

"Benditos sejam os amigos que acreditam na tua verdade, ou te apontam a realidade;

Porque amigo é a direção, é a base, quando falta o chão!" Machado de Assis (Poema Benditos)

Conheci a professora Sílvia Lane nos idos dos anos noventa, ao ler seu livro Psicologia Social: O homem em movimento como requisito para o exame de seleção ao mestrado. Posteriormente, Novas veredas da Psicologia Social. Apaixonei-me por suas idéias tão claras e sensíveis. E torci para conhecê-la, o que seria facilitado se fosse aprovada para cursar o mestrado.
Comecei a freqüentar o seu Núcleo, logo no primeiro ano do mestrado. Senti-me afortunada, por acompanhar de perto a sua incessante construção do edifício do saber em Psicologia Social. E ali permaneci durante quase dez anos, ouvindo, aprendendo e "fermentando idéias" e alimentando ações. 